\title{
Holocene landscape changes and wood use in Patagonia: Plant macroremains from Cerro Casa de Piedra 7
}

\author{
Laura Caruso Fermé ${ }^{\prime}$ and Maria Teresa Civalero²
}

\begin{abstract}
This paper studies the different practices employed in the acquisition of woody material used by hunter-gatherer societies from the northwestern region of the Santa Cruz Province, Argentine Patagonia, during the early and middle Holocene. In addressing this theme, we study carbonized and non-carbonized wood recovered from six stratigraphic levels from the Cerro Casa de Piedra 7 site. This research revealed that during the lowest level of occupation, a distinct range of woody species were utilized; these were subsequently absent in the rest of the stratigraphical levels studied. In fact, all the other levels analyzed presented the homogeneous presence of a single plant species: Nothofagus pumilio. This species has the largest representation among both the charcoal and uncharred wood fragments of the six levels studied. The study of the assemblage samples allowed us to identify differences between the various archaeological levels, which could be the product of behavioral and/or environmental differences.
\end{abstract}

\section{Keywords}

archaeobotany, Holocene, hunter-gatherers, landscape, Nothofagus pumilio, South Patagonia

Received 6 June 2013; revised manuscript accepted 7 November 2013

\section{Introduction}

Human evolution and history is intimately tied to the existence of the wider plant world. Therefore, the management of wood resources by humans provides a crucial insight into the natural environment of the groups that inhabited it. This insight refers not only to the plants but also to all the elements that directly or indirectly interact and influence the management of this resource and its combustion process (Chabal et al., 1999; Dufraisse, 2006; Théry-Parisot, 1998; Zapata, 2007, among others).

In the acquisition of woody material, there are several parameters that play a fundamental role. For instance, the availability and abundance of species in the environment was certainly an important factor. Other factors that condition the management and use of the available wood include the function and duration of a site occupation, the function/functions assigned to the combustion structures and the moment of this combustion, and the mobility range of the human groups that require and acquire this raw material (see among others, Allué, 2002; Carrión, 2005; Chabal, 1997; Dufraisse, 2008; ThéryParisot and Henry, 2012).

The seeking and obtaining of fuel is one of the commonest daily activities carried out by societies in general (Picornell Gelabert, 2009; Tabuti et al., 2003). Wood acquisition strategies partly reflect the social organization of human groups, their lifestyles, and their perception of the environment (Biran et al., 2004; Henry et al., 2009; Picornell Gelabert et al., 2011; Zapata Peña et al., 2003). These strategies have changed throughout history, depending on landscape characteristics and evolution, shifts in technology, and varying social requirements. In this respect, the study of plant residues helps elucidate the role played by this resource within a given society, thereby providing a better approximation of the social and economic dynamics of a group (Caruso Fermé et al., 2008). However, despite the rich record of woody plants from archaeological sites and its proven potential for assessing past human behavior, its study - both of combustion and other uses - is still rare in Patagonian hunter-gatherer archaeological research (Caruso Fermé, 2008). With this in mind, we studied charred and non-carbonized woody plant remains from six stratigraphic levels, or layers, from the Cerro Casa de Piedra 7 (CCP7) archaeological site, Santa Cruz Province, Argentina (Caruso Fermé, 2012; Caruso Fermé et al., 2013a, 2013b).

The exceptional preservation of plant materials from CCP7 and its long occupation sequence (e.g. Aschero, 1996; Civalero and Aschero, 2003; Civalero et al., 2007; De Nigris, 2004) made it an ideal case study concerning the role of plant resources in Patagonian hunter-gatherer economies. The overall objective of this paper is, first, to understand how woody material was acquired in a context of high residential mobility (Aschero, 1988; Aschero et al., 1992-1993). Second, we analyze the effects of environmental change and its influence on woody raw material procurement strategies among Patagonian hunter-gatherer groups.

\footnotetext{
Universitat Autònoma de Barcelona, Spain

${ }^{2}$ CONICET, Argentina
}

\section{Corresponding author:}

Laura Caruso Fermé, Universitat Autònoma de Barcelona, Bellaterra, Cerdanyola del Vallès, 08193 Barcelona, Spain.

Email: Icarusoferme@gmail.com 

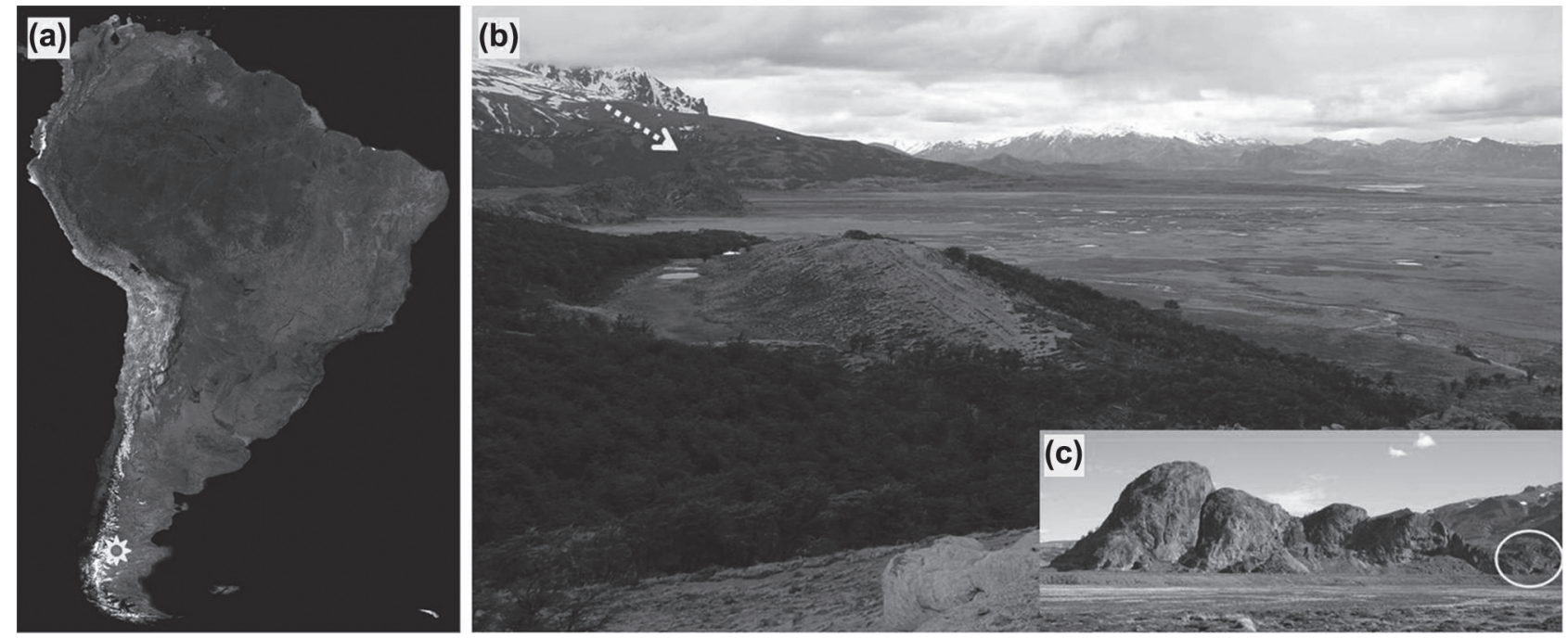

Figure I. (a) Location of Casa de Piedra Hill in South America, (b) Casa de Piedra Hill and (c) Cerro casa de Piedra 7 site (CCP7).

\section{The CCP7 site in its present context}

Location of the site

The site CCP7 $\left(47^{\circ} 57^{\prime} \mathrm{S}, 72^{\circ} 05^{\prime} \mathrm{W}\right)$ is located in the mountains of the Perito Moreno National Park, in the northwestern region of the Santa Cruz Province, Argentina (Figure 1). It is part of a rhyolitic volcanic hill that has several caves and rock-shelters facing northwards. It is located approximately $2 \mathrm{~km}$ east-southeast of Burmeister Lake, which together with the Lake Belgrano, Azara Lake, Nansen Lake, and Mogote Lake form a large glacial basin situated in Argentine Patagonia.

The oldest radiocarbon dates from this complex come from Cave 7. The site has been intensively studied and has produced evidence of human occupation dating to between $c$. 10,600 and $3400{ }^{14} \mathrm{C}$ yr BP (Figure 2). This remarkable continuity of occupation covers a large swathe of the Holocene. An occupation richness underpinned by a range of different types of evidence such as faunal and lithic assemblages in association with hearths. Apart from the presence of lithics, the cold and dry conditions of the cave favored the preservation of guanaco (Lama guanicoe) skin, bones, plant vein threads, and vegetable fiber, as well as, wood and other animal bone (Civalero and Aschero, 2003). CCP7 is a multiple activity locale (Borrero, 1987), which probably served as a base camp at which multiple subsistence activities took place. Geomorphological studies suggest that the cave was abandoned for some time because of a landslide c. $3500 \mathrm{yr}$ BP (Aschero et al., 2005). After that, humans occupied the cave on a temporary basis, while they exploited various terrestrial resources from nearby places (Civalero and Franco, 2003; Civalero et al., 2006-2007).

Present-day vegetation. Environmental variability in Patagonia is conditioned by a number of factors. These factors include latitude, landscape relief, and the location of the highlands with respect to the ocean (Cabrera and Willink, 1973; Morello, 1984). The presence of humid wind currents from the Pacific is a crucial determinant - among other factors - in the existing vegetation types. Precipitation declines progressively from West to East establishing a series of vegetation types such as forest, grass steppe, bush-grass steppe, and bush steppe (León et al., 1998; Movia et al., 1987; Soriano, 1956). In Continental Patagonia, the forest area stretches between latitudes $39^{\circ} \mathrm{S}$ and $53^{\circ} \mathrm{S}$ along the Cordillera de los Andes and exists as a narrow 120-km-wide by 2000-km-long environment.

The $47^{\circ} \mathrm{S}$ parallel coincides with an important boundary in Patagonian vegetation distribution (Cabrera and Willink, 1973;

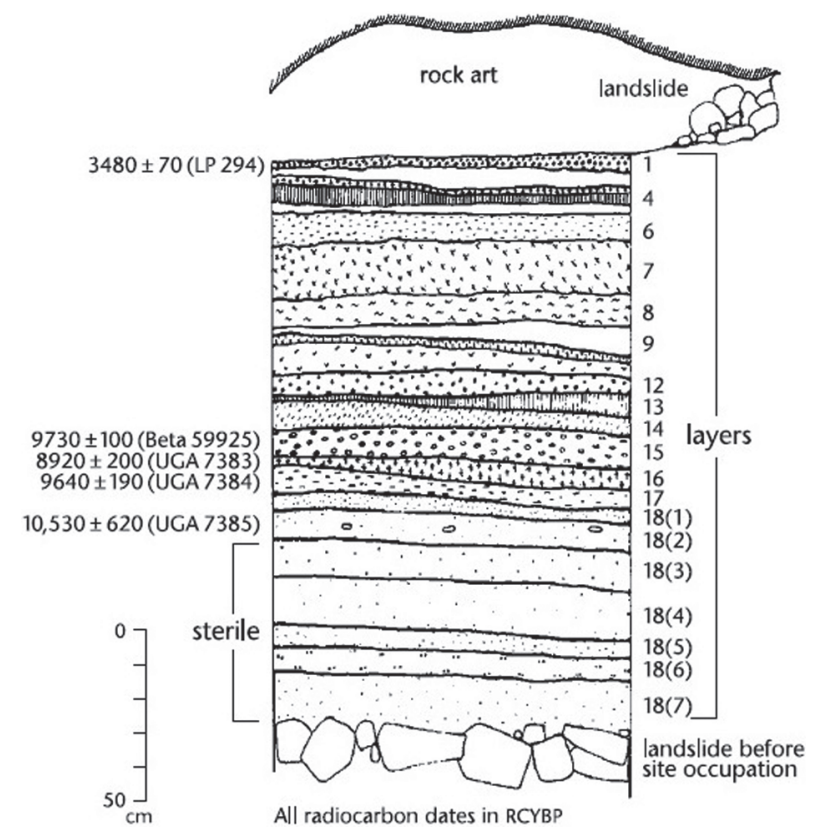

Figure 2. Stratigraphy and radiocarbon dating of CCP7 site. RCYBP: radiocarbon years Before Present.

León et al., 1998). To the north, where rainfall is more abundant, the forest is characterized by a greater biodiversity than that of the southern Patagonian forests (Cabrera, 1976; Roig, 1998).

The site of CCP7 is located near to three clearly defined environments:

1. The steppe, represented mainly by dense patches of Festuca pallescens and a smaller number of Nardophyllum obtusifolium;

2. A transition zone with vegetation characterized mainly by Nothofagus antarctica and Nothofagus pumilio;

3. The forest, consisting almost exclusively of N. pumilio, where the mean temperature is slightly higher and the wind is not as harsh.

The forested area divides into two types: continuous and discontinuous forest. Continuous forest is large and dense, reaching up to $1500 \mathrm{~m}$ a.s.l. It consists mainly of four tree taxa: $N$. pumilio, Nothofagus betuloides, $N$. antarctica, and Drimys winteri. Furthermore, the species Embothrium coccineum, Maytenus magellanica, 
and Pilgerodendron uviferum can be found in the most humid areas of this type of forest.

Discontinuous forests, however, are usually located at lower altitudes and are more open, less dense but with a greater variety of undergrowth. The tree layer is composed almost exclusively of N. antarctica (Mermoz, 1998; Movia et al., 1987; Peri, 2004). Among the most common species found in the undergrowth are Empetrum rubrum, Mulinum spinosum, N. obtusifolium, Pernettya mucronata, Berberis buxifolia, Chiliotrichium diffusum, Baccharis magellanica, Senecio miser, Senecio patagonicus, Discaria chacaye, Adesmia boronioides, Anarthrophyllum rigidum, and Escallonia rubra (e.g. Guerrido and Fernandez, 2007; Kofalt and Mascó, 2000, 2004; Mermoz, 1998).

Historical development of the landscape and vegetation. A number of palynological studies indicate that there were important changes in vegetation and climate during the late PleistoceneHolocene transition in this area (Mancini, 1998; Mancini et al., 1997; Markgraf et al., 1996; Páez et al., 1994). Between c. 10,600 and $9600{ }^{14} \mathrm{C}$ yr BP pollen sequences suggest an increase in Nothofagus, probably related to increased temperature and rainfall. Nothofagus do not tend to be very dense, so this increase in Nothofagus forests would have enhanced the growth and spread of other grasses and shrubs (Mancini, 2009).

Between c. 8000 and $7000{ }^{14} \mathrm{C}$ yr BP, there was a further expansion of Nothofagus forest (Mancini, 2002), followed by a percentage decrease in Nothofagus for the period between 7000 and $6000 \mathrm{yr}$ BP. According to Mancini (2002), this may well have led to a reduction in the overall forested area.

Between c. 5800 and $3200{ }^{14} \mathrm{C}$ yr BP, shrub taxa increased Asteraceae subf. Asteroideae, Solanaceae, Berberis, and Mulinum - as well as the ubiquitous Nothofagus tress. This suggests a rise in summer temperature associated with climatic conditions that increased the availability of water. The pollen associated to this period suggests the development of a forest-steppe shrub ecotone. This same ecotone exists at present in areas close to the Andes themselves (Mancini et al., 1997, 2002, 2007).

After c. $3000 \mathrm{yr}$ BP, the increase in Nothofagus and the decrease in shrub taxa - Asteraceae subf. Asteroideae, Mulinum, Empetrum, and Berberis - indicate episodic increases in temperature, although not significant enough to enable the continued growth and establishment of the forest.

Between c. 2700 and $2000 \mathrm{yr}$ BP, the discontinuous Nothofagus forest near Cerro Casa de Piedra reaches maximum level of development (Mancini, 2002, 2007, 2009). There is a striking similarity between the pollen spectrum of this period to that of the present day suggesting the continuing existence of discontinuous Nothofagus forests (Heusser, 1995).

Between c. 1200 and $250 \mathrm{yr}$ BP, the pollen sequences show shrub steppe expansion, suggesting an increase in temperature comparable with those from current records (Mancini et al., 2002, 2007).

\section{Materials and methods}

\section{Sampling}

Plant remains were recovered through the dry sieving of all the sediment from excavation. The mesh size of the sieves used was $2 \mathrm{~mm}$. This sampling method was rigorously and systematically applied during the various archaeological field seasons to each of the excavated levels at CCP7 (Caruso Fermé, 2012; Caruso Fermé et al., 2013a). The extreme dryness of the cave allied to our systematic and complete sampling of each layer of excavation permitted the recovery of abundant plant remains: wood charcoal, uncharred wood, pieces of bark, leaves, seeds, and two wooden artifacts, one from Layer 17 and the other from Layer 6. Research into these artifacts has been described in other articles (see Caruso
Fermé, 2012; Caruso Fermé et al., 2013a), and is not repeated here, as it is not the focus of this study.

The archaeobotanical study comprised the analysis of carbonized and un-carbonized woody material remains from six stratigraphic levels: $17,10,8,6,5$, and 1 . The samples studied were from material dispersed within the excavation sediment layers and from distinct combustion structures (hearths). Stratigraphic Levels 6 and 17 only have a single combustion structure each; Levels 10, 8, and 1 have two structures; and Level 5 has three. From some of these structures, only carbon fragments were recovered, while from others both carbon fragments and noncarbonized wood remains were found (Table 1).

\section{Botanical identification}

Wood identification was done by performing a clean cut on each charcoal fragment, with the intention of obtaining the three anatomical planes: transversal, longitudinal radial, and longitudinal tangential. Given the dryness and preservation of the recovered non-carbonized wood, it was possible to apply the same technique to these types of samples. Samples were analyzed using a light microscope with optical reflection of the light-dark field (Olympus BX51 and MZ16A Leica) and were then compared with present-day wood reference samples.

\section{Analysis of bark}

In different layers within the excavation, large fragments of bark were recovered. Each of these was studied, recording the length, width, thickness, and surface features.

\section{Results}

This study is based on the analysis of 1662 fragments of charred and non-carbonized wood. The level of determination was mainly at the species level; however, in some cases, the limited differences between the species of some genera made it impossible to separate them. Classifications of taxa A, B, C, and D were used to refer to certain fragments whose analysis did not allow their identification to any type, family, or species represented archaeologically or in the present-day reference collection and/or in the bibliographic material consulted. Nevertheless, their variable microscopic anatomical characteristics did not permit us to lump them into the 'Indeterminate' category.

The taxonomic analysis of material recovered from the various excavated levels revealed the presence of 15 taxa (Tables 2 and 3). This first analysis showed that the taxa identified and their proportions were paleoecologically consistent and very similar to those observed among present-day vegetation.

Across all the studied levels, with the exception of Level 17, cortex fragments were recovered. The dimensions, and especially, the thickness of the bark (Table 4) fragments suggest that they belong to a species of tree. The results of the taxonomic analysis and the marked roughness and longitudinal cracks of different pieces of bark (Donoso and Donoso 2006; Donoso et al., 2006; González et al., 2006) might suggest that the fragments recovered at different levels correspond to timber of $N$. pumilio. However, the possibility that it might be $N$. antarctica cannot be ruled out.

\section{Level I $7\left(9390 \pm 40{ }^{14} \mathrm{C}\right.$ yr BP $)$}

Our study shows the presence of 10 taxa in among the scattered material and two among the charcoal of a hearth. Among the scattered charred material, eight taxa were identified $-N$. pumilio, $N$. antarctica, E. rubrum, A. rigidum, Berberis sp., Rhamnaceae family, and taxa A and B - while six were identified in the noncarbonized material ( $N$. pumilio, A. rigidum, Berberis sp., E. rubra, Fabaceae and taxa A). As shown in Table 2, the species 


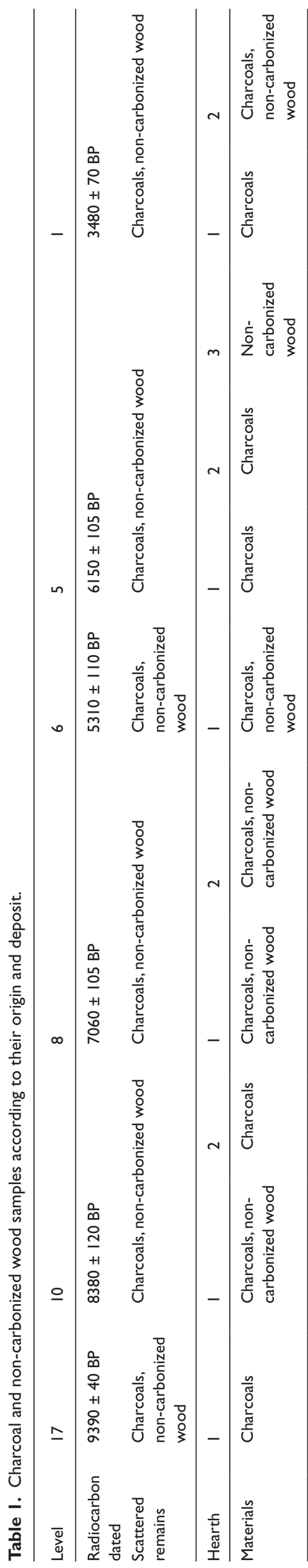

with the highest representation among the scattered charcoal was N. pumilio $(72.16 \%)$, and among the scattered non-charred wood, it was E. rubra $(51.02 \%)$. By way of contrast, in the only hearth registered at this level, only two taxa were identified: $N$. antarctica and N. pumilio (Table 3).

\section{Level IO (8380 $\pm 120{ }^{14} \mathrm{C}$ yr BP $)$}

Our study shows a lower level of floristic variety in this level compared with Level 17. The taxonomic study of the scattered material identified the presence of four taxa: N. pumilio, $N$. antarctica, Berberis sp., and Taxon C; N. pumilio being the only one present among the charcoal (Table 2). Among the uncharred wood samples, $N$. pumilio is the most represented species at $87.80 \%$, followed by a much lower percentage of taxa C (7.32\%), Berberis sp. (3.66\%), and finally a single fragment of $N$. antarctica $(1.22 \%$; Table 2). We also recovered 16 fragments of bark, 11 among the scattered material and 5 from the Hearth 1 (Table 4).

\section{Level $8\left(7060 \pm 105^{14} \mathrm{C}\right.$ yr BP $)$}

The anthracological spectrum of Level 8 is qualitatively different from that of the previously analyzed deposit. Taxonomic analysis of scattered charcoal and scattered uncharred wood allowed identification of seven taxa: N. pumilio, E. coccineum, Berberis sp., family Fabaceae taxa, and taxa A, B, and C (Table 2). Two of these are common both among scattered charcoal and scattered uncharred wood $-N$. pumilio and taxa A - two are present only among the charcoal (E. coccineum and taxa B) and three only among the uncharred remains (Berberis sp., Fabaceae, and taxa C). Among the material from Hearth 1, four taxa were identified: N. pumilio, taxa A and D, and taxa of Rhamnaceae (Table 3). In Hearth 2, there were three taxa (Berberis sp., A. rigidum, and taxa A), while one - N. pumilio - was common to both hearths. Berberis sp., N. pumilio, and taxa A were recovered within the scattered material samples. A. rigidum was only present in this structure. We recovered 18 fragments of bark, 14 among the scattered material and 4 from the Hearth 2 (Table 4).

\section{Level $6\left(5310 \pm 110^{14} \mathrm{C}\right.$ yr BP $)$}

Analysis of the scattered material from this level revealed a list of four taxa: N. pumilio, A. rigidum, Anarthrophyllum sp., and taxa A. The first was documented among samples of charcoal and uncharred wood, while A. rigidum, Anarthrophyllum sp., and Taxon A were only found among uncharred wood (Tables 2 and 3 ). The list of identified taxa obtained for the flora samples from Hearth 1 was longer than that of the scattered material. Seven taxa were noted: N. pumilio, Berberis sp., A. rigidum, Anarthrophyllum, Fabaceae, and taxa A and D (Table 3). The analyzed material shows that only one type of wood was employed in the hearth $-N$. pumilio. This same taxon was the only one represented among the scattered charcoal found. Both results contrast with the registered floristic variety observed both in the uncharred woods from the hearth as well as the uncharred scattered material recovered. We also recovered 57 fragments of bark, 12 among the scattered material and 45 from Hearth 1 (Table 4).

\section{Level $5\left(6150 \pm 105^{14} \mathrm{C}\right.$ yr BP)}

Among the scattered woods from this level, five taxa were identified: N. pumilio, Berberis sp., Fabaceae, and taxa C and D, with Nothofagus present in higher percentages than the other four taxa. Among the carbonized material, only one species was represented $-N$. pumilio. The three hearths were homogenous in the woody material burned. In Hearths 1 and 2, all the charcoal retrieved came from $N$. pumilio, while all the woods in Hearth 3 were also 


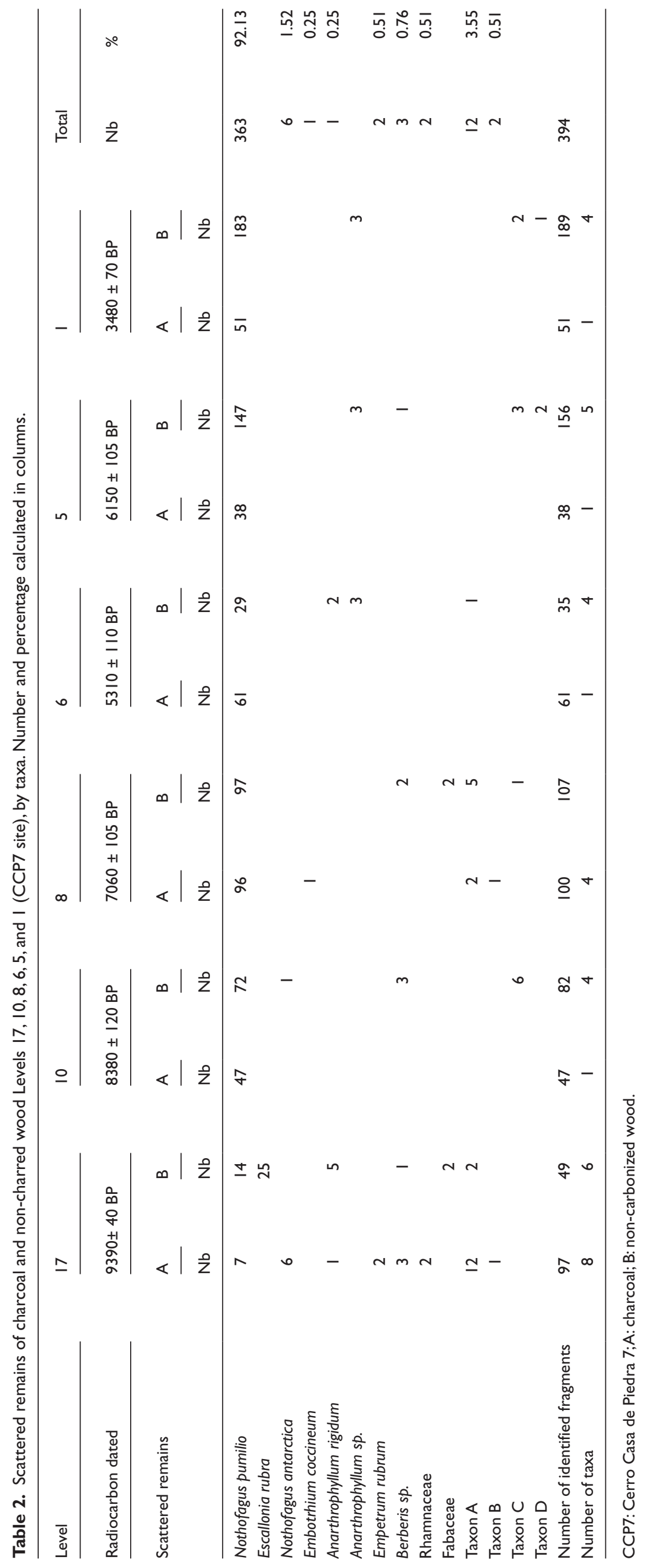




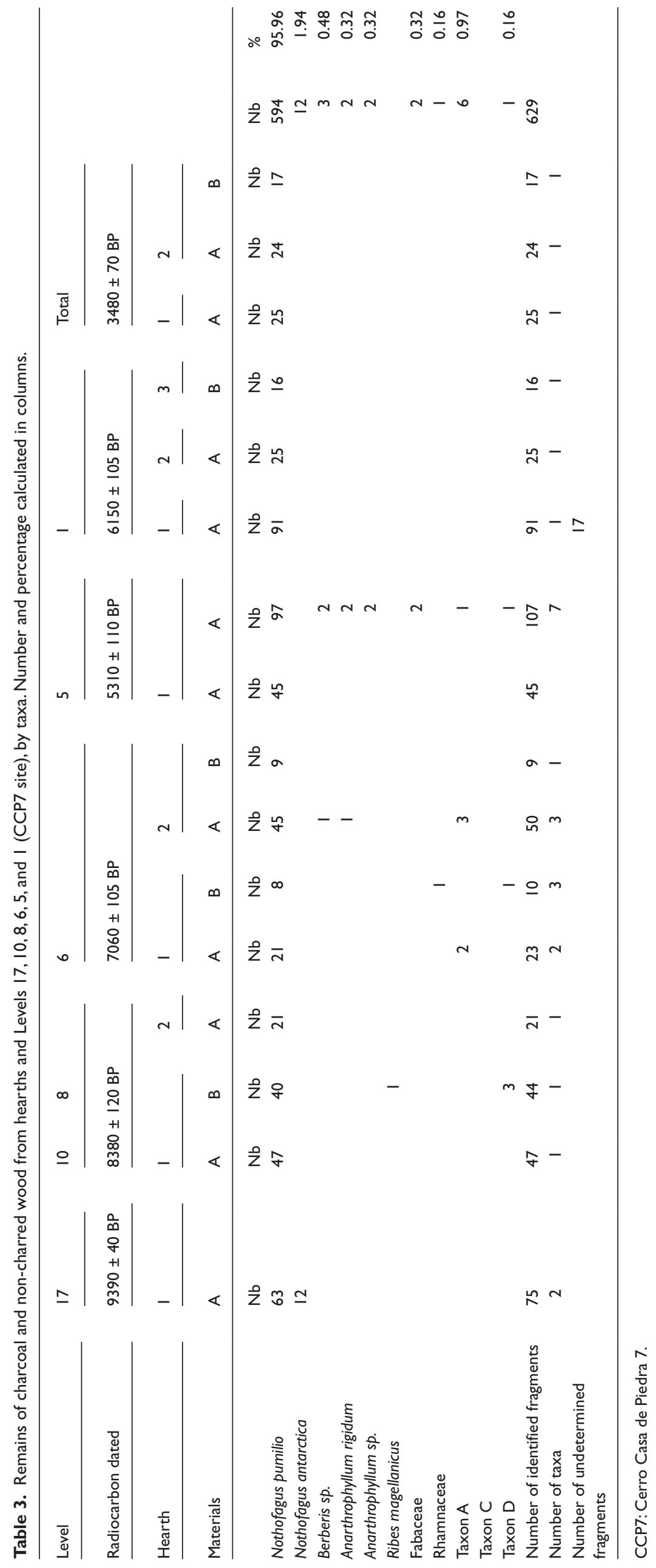


Table 4. Bark samples Levels I0,8,6,5, and I (CCP7 site), by to their length, width and thickness.

\begin{tabular}{|c|c|c|c|c|c|}
\hline $\begin{array}{l}\text { Level and radiocarbon } \\
\text { dated }\end{array}$ & Samples & $\begin{array}{l}\text { Number of bark } \\
\text { fragments }\end{array}$ & Length $(\mathrm{mm})$ & Width (mm) & Thickness (mm) \\
\hline \multirow[t]{2}{*}{ Level I0 (8380 \pm I20 BP) } & Scattered remains & 11 & $47.14-15.72$ & $33.66-9.98$ & $7.18-3.02$ \\
\hline & Hearth I & 5 & $25.21-16.1$ & $31.96-13.27$ & $7.01-4.87$ \\
\hline \multirow[t]{2}{*}{ Level $8(7060 \pm 105$ BP $)$} & Scattered remains & 14 & $51.4 \mid-14.25$ & $18.86-939$ & 8.7II-3.3 \\
\hline & Hearth 2 & 4 & $31.68-15.51$ & $27.82-7.71$ & $7.06-3.06$ \\
\hline \multirow{2}{*}{ Level 6 (5310 \pm I 10 BP $)$} & Scattered remains & 12 & $57.11-19.59$ & $66.85-9.68$ & $|3.0|-4.05$ \\
\hline & Hearth I & 45 & $75.35-21.49$ & $89.36-11.16$ & $15.16-4.74$ \\
\hline \multirow[t]{2}{*}{ Level $5(6150 \pm 105 \mathrm{BP})$} & Scattered remains & 26 & $78.23-20.2$ & $38.2-11.04$ & $12.15-4.12$ \\
\hline & Hearth 2 & 1 & 31.06 & 9.83 & 2.03 \\
\hline \multirow[t]{2}{*}{ Level I $(3480 \pm 70 \mathrm{BP})$} & Scattered remains & & $60.14-14.52$ & $28.63-7.21$ & $10.23-1.55$ \\
\hline & Hearths I and 2 & & $45.01-15.3$ & $38.62-11.52$ & $10.88-1.97$ \\
\hline
\end{tabular}

CCP7: Cerro Casa de Piedra 7.

of the same wood. It is important to note that every fire is a reflection of the last combustion. However, the results revealed that both among the scattered material and in the three hearths N. pumilio was the most represented species, or in fact the only one plant species present (Tables 2 and 3). We also recovered 27 fragments of bark, 26 among the scattered material and 1 from the Hearth 2 (Table 4).

\section{Level I $\left(3480 \pm 70{ }^{14} \mathrm{C}\right.$ yr BP $)$}

Analysis of the scattered uncharred wood revealed a list of four different taxa: N. pumilio, Berberis sp. and taxa C and D. N. pumilio is the species with the highest percentage representation within the sample. Among the scattered charcoal, only a single plant species was identified: $N$. pumilio (Table 2). The result of the analysis of the Hearths 1 and 2 shows that a single species, $N$. pumilio, was represented (Table 3). This is the same result as that from Levels 5 and 10. We recovered 18 fragments of bark, 16 among the scattered material, 4 from the Hearth 1, and 25 from the Hearth 2 (Table 4).

\section{Discussion}

The long archaeological sequence studied (from 9390 to $3480{ }^{14} \mathrm{C}$ yr BP) allowed for a discussion into the modalities of woody material acquisition among hunter-gatherers of this area. Furthermore, the data thus obtained gave us an insight into the use of the forest by hunter-gatherers from the early to the late Holocene.

The presence of certain tree taxa within Level 17 implies the existence of a forest environment. However, the presence of steppe taxa also suggests the proximity of steppe environments. The high percentage of $N$. pumilio shows that the forest was an environment that was used recurrently by the hunter-gatherers occupying the cave site CCP7.

Analysis from Level 10 strongly suggested the mono-specific use of woody material for combustion, with only the species $N$. pumilio represented among charcoal from the fire places. However, the uncharred wood fragments do show certain taxonomic diversity when compared with the homogeneity found among the carbonized material. The uncharred wood comes from five taxa: Berberis sp., N. antarctica, N. pumilio, Ribes magellanicus, and taxa C. However, the dominant taxa among uncharred wood is $N$. pumilio. Pollen sequence results from various archaeological sites located in the Perito Moreno National Park and in other southern latitudes $\left(50^{\circ} \mathrm{S}\right)$ show that during the occupation of Level 10 , there is a generalized expansion of Nothofagus forest (Bamonte and Mancini, 2009; Mancini, 2002, 2007). Studies on the evolution of the Cardiel Lake shoreline indicate that the period between c. 10,000 and 7000 BP was very humid (Stine and Stine, 1990), this would have facilitated forest expansion.
The wider range of taxa identified for Level 8 suggests a change in the environment or in the human consumption of woody material at the site. According to Stine and Stine (1990), this would relate to a dry period shown by a declining shoreline level at Cardiel Lake. The pollen for the period between 7000 and 6000 yr BP shows a decrease in the frequency of Nothofagus, which in turn could pertain to a reduction in forest cover (Mancini, 2002). Nevertheless, the percentages of $N$. pumilio found at this level do not suggest a lower consumption of this species.

The floristic richness found in the analysis of the uncharred wood from Level 6 coincides with that found in the pollen studies for the period 5800-3200 yr BP. This period is characterized by increased shrub taxa and the genus Nothofagus, together with the development of a forest-steppe shrub ecotone. This forest-steppe shrub ecotone currently grows as far west as the east flanks of the Andes (Mancini et al., 1997, 1998, 2002). However, this modern spread of the ecotone may be due to anthropogenic factors.

The strong representation of $N$. pumilio within Level 1 could be related to an increase in the growth of Nothofagus and foreststeppe ecotone, marked by a decrease in shrub taxa. This environment would have been similar to the one at present, and the pollen records show that this environment begun at c. $3000{ }^{14} \mathrm{C}$ yr BP (Mancini et al., 1997).

On the basis of the documented archaeological taxonomic diversity uncovered, we suggest that the paleoenvironment of the settlement shared broad similarities with present-day ecotonal features of the area around Cerro Casa de Piedra. The results of the taxonomic analysis show qualitative differences between carbonized and non-carbonized material from the different levels (Figure 3). Throughout the sequence, we can see a dramatic reduction in the taxa used for combustion. During the early occupation of the cave - Level 17 - there was greater variety of woody species employed compared with the later levels; a minimum of 8 species were used. Level 8 also displays a similar taxonomic diversity to Level 17, with 6 taxa to account for. Yet, only one of these is represented in significant numbers. Across the other levels, we have the homogenous presence of a single species type: $N$. pumilio.

In the case of non-carbonized wood, we also noted changes along the length of the chronological sequence. These results are in total variance to those from the carbonized samples. The number of taxa represented oscillates between 8 and 4, and in marked difference to the carbonized samples - aside from Level 17 - the secondary taxa have a higher presence within the assemblage (between $18 \%$ and $4 \%$ depending on the level). Even though the presence of $N$. pumilio is high across the whole of the sequence, we see greater diversity in non-carbonized wood taxa throughout the different occupation levels. In Level 17, for example, there is predominance of a shrub taxon-E. rubra-among the dispersed non-carbonized wood. This taxon has not been documented in the 


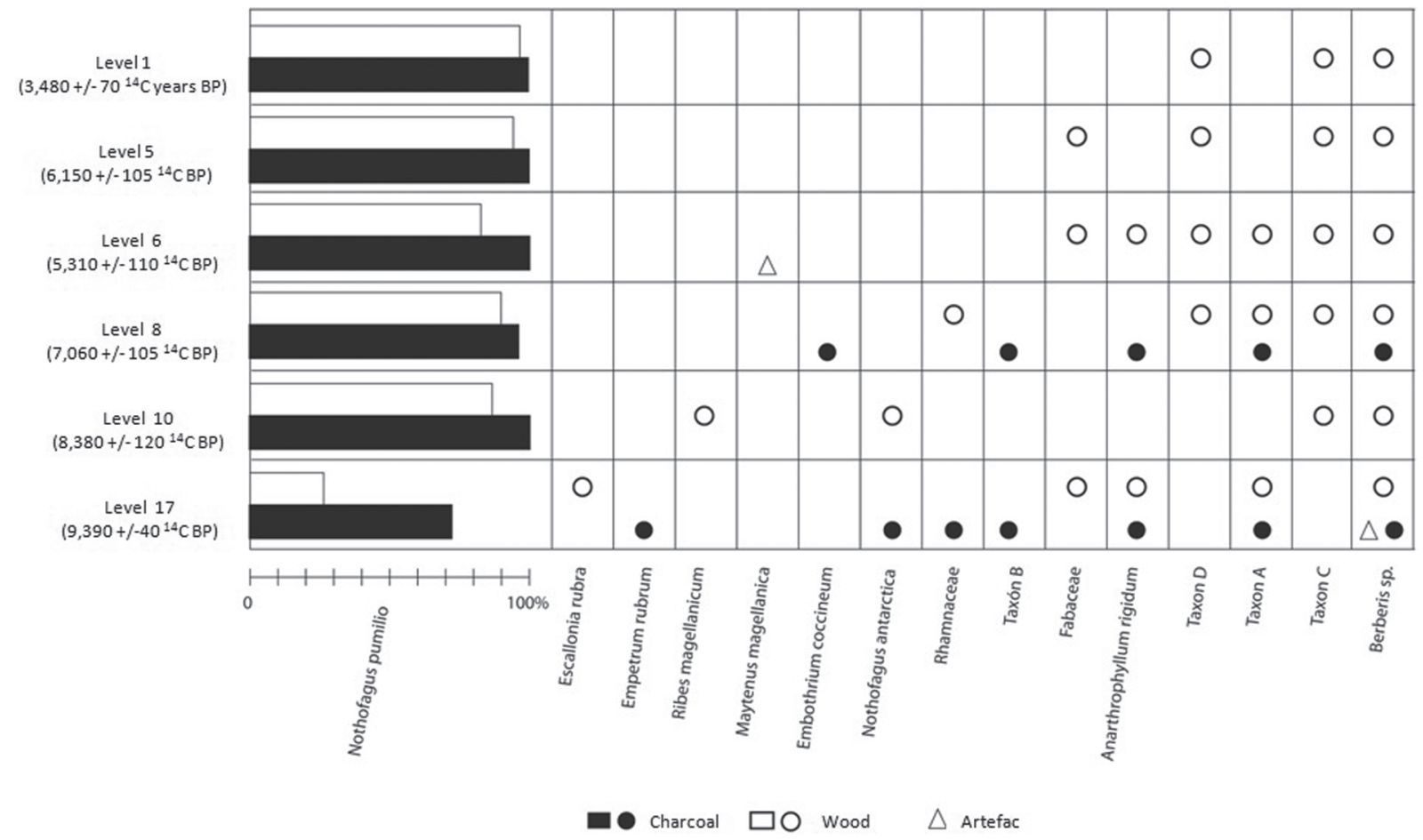

Figure 3. Antracological sequence of Cerro Casa de Piedra 7 site (Levels 17, 10, 8, 6, 5, and I).

carbon samples or in the wood samples of the other level (Table $3)$. It is important to highlight that the object recovered from Level $6\left(5310 \pm 110{ }^{14} \mathrm{C}\right.$ yr BP) was made from M. magellanica. This taxon was not documented either among the carbonized or non-carbonized wood samples from any of the other six levels in this study (Caruso Fermé, 2012; Caruso Fermé et al., 2013a).

Despite the continuity observed in the exploitation of environments, there is a difference in taxonomic diversity recorded for charcoal and uncharred wood across the sequence. The taxonomic results show great heterogeneity among the uncharred wood and a marked homogeneity in the case of the charcoal. Various factors might underpin this difference. For instance, while charcoal samples are the result of a single activity (combustion), the non-carbonized wood could well be linked to both combustion and to other activities, such as the manufacture of tools. The recovery of two artifacts, one from Level 17 and the other from Level 6 is a clear indication of the use of wood for other purposes, in this case tool production. Therefore, the taxonomic diversity recorded within the cave could be due to a variety of human activities.

\section{Conclusion}

The analysis of charred and non-carbonized wood from the CCP7 archaeological site permitted a study into the effects of environmental change and their influence on plant procurement by the hunter-gatherers who inhabited the site. The analysis gave us a new insight into the use of the forest and nearby environment for procurement of woody plant resources designated for different tasks.

The results of the taxonomic study of charcoal and non-carbonized wood yielded important environmental information. Furthermore, their study also opened avenues into a discussion concerning the modalities of woody material acquisition among hunter-gatherers who inhabited the CCP7 site throughout the different periods studied.

The results of the taxonomic analysis yielded qualitative differences between the six levels studied (Levels 17, 10, 8, 6, 5, and 1). Given the number of usable plants in the environment, the woody resources used by hunter-gatherer societies changed through time. In this respect, the case for the early Holocene (Level $17-9390 \pm 40{ }^{14} \mathrm{C}$ yr BP) is interesting given that this represents one of the earliest human occupations in the study area. During this period, there is greater diversity of woody species used for combustion with respect to later periods, with the exception of Level 8. Throughout the chronological sequence, there is a drastic reduction in the number of taxa used for combustion.

The results of the taxonomic analysis on dispersed charcoal and that from the hearths demonstrate the homogeneous use of $N$. pumilio as fuel for all levels with the exception of Levels 17 and 8. The marked presence of this species across the length of the studied sequence could well be an indication of hunter-gatherer interaction with forest-type spaces. It is therefore important to ask whether the shifts in wood procurement strategies were as a consequence of changes and evolution of the landscape or rather due to the particular circumstances of the human groups. Throughout all the levels, we saw the intense use of tree species for combustion; bushes were also collected but in much lower overall percentages. The almost exclusive use of $N$. pumilio as fuel and the taxonomic heterogeneity observed among the uncharred woods suggest that selective use of woody species for combustion and for other activities. Indeed, the recurrent use of tree species for combustion throughout the length of the sequence could well be the result of behavior rather than due to environmental conditions. Nevertheless, it is reasonable to assume that the availability and diversity of these tree species in the environment conditioned the procurement strategies and use of this woody material.

Civalero and De Nigris (2005) previously stated that during the early Holocene (Level 17) at this site, there was a broad-spectrum use of available subsistence resources seen in the increase in processing and consumption marks on bone, a higher incidence of scrape marks along guanaco ribs (L. guanicoe), and the presence of bird remains. Bird remains are not found in any of the other levels in the cave. This is the pattern that one would expect from an exploration or incipient human occupation model for a given area (Borrero and Franco, 1997). The exploitation strategy associated to the exploration or incipient occupation model stresses the availability and encounter rates of different fauna as the main factor in their exploitation. This generalist strategy is underpinned by 
the lithic technology uncovered that emphasizes versatility of use (sensu Nelson, 1991).

The diversity found within the carbonized wood of the early Holocene coincides with the views of Civalero y De Nigris (2005) who suggested a premeditated adjustment on the side of the hunter-gatherer groups with regard to their technological and subsistence strategies to minimize risk and uncertainty. The same strategies have been noted in the charcoal analysis where the diversity of wood employed was probably an important factor in overcoming the exiting conditions of uncertainty and predictability necessary for survival.

\section{Acknowledgements}

Special thanks go to Nora Franco, Damián Bozzuto and Ester Verdún Castelló for their comments and for their insightful corrections of the original manuscript.

\section{Funding}

This research has been funded by a doctoral grant of the Ministerio de Cultura y Educación de España presented to the first author (LCF), which was then carried out within the remits of the HUM2006-01129 Project.

\section{References}

Allué E (2002) Dinámica de la vegetación y explotación del combustible leñoso durante el Pleistoceno Superior y el Holoceno del Noreste de la Peninsula Ibérica a partir del análisis antracológico. Doctoral Thesis, Universitat Rovira i Virgili.

Aschero CA (1988) De punta a punta: producción, mantenimiento y diseño en puntas de proyectil precerámicas de la Puna argentina. In: Precirculados Simposio. IX Congreso Nacional de Arqueología Argentina, pp. 219-229. Edited by Facultad de Filosofía y Letras, Universidad de Buenos Aires.

Aschero CA (1996) El área Río Belgrano-Lago Posadas (Santa Cruz): problemas y estado de problemas. In: Goméz Oteror J (ed.) Arqueología sólo Patagonia. Ponencias de las Segundas Jornadas de Arqueología de la Patagonia. Puerto Madryn: Centro Nacional Patagónico, pp. 17-26.

Aschero CA, Bellelli C and Goñi RA (1992-1993) Avances en las investigaciones arqueológicas del Parque Nacional Perito Moreno, Provincia de Santa Cruz, Patagonia Argentina. Cuadernos del Instituto Nacional de Antropología y Pensamiento Latinoamericano 14: 143-170.

Aschero CA, Goñi RA, Bellelli C et al. (2005) Holocenic Park: arqueología del Parque nacional Perito Moreno (PNPM). Anales de la administración de Parques Nacionales 17: 71-119.

Bamonte FP and Mancini MV (2009) Características ambientales del econoto Bosque Estepa durante el Holoceno medio (Santa Cruz, Argentina). In: Salemme M, Santiago F, Álvarez M, et al. (eds) Arqueología de Patagonia: una mirada desde el confin. pp. 881-892.

Biran A, Abbot J and Mace R (2004) Families and firewood: A comparative analysis of the costs and benefits of children firewood collection and use in two rural communities in subSaharan Africa. Human Ecology 32: 1-25.

Borrero LA (1987) Variabilidad de sitios arqueológicos en Patagonia meridional. In: Primeras Jornadas de Arqueología de la Patagonia. Trelew, pp. 41-45. Edited by Gobierno de la provincia de Chubut, Dirección de Cultura de la provincia de Chubut.

Borrero LA and Franco NV (1997) Early Patagonian hunter-gatherers: Subsistence and technology. Journal of Anthropological Research 53: 219-239.

Cabrera AL (1976) Regiones fitogeograficas argentinas. In: Enciclopedia Argentina de Agricultura y Jardinería, 2nd edition. Buenos Aires: ACME S.A.C.I., 85 pp.
Cabrera A and Willink A (1973) Biogeografía de América Latina (Monografía 13, Serie de Biología). Washington, DC: Programa Regional de Desarrollo Científico y Tecnológico, Secretaria General de la OEA.

Carrión Y (2005) La vegetación mediterránea y atlántica de la Península Ibérica: Nuevas secuencias antracológicas. Valencia: Servicio de Investigación Prehistórica, Diputación Provincial de Valencia.

Caruso Fermé L (2008) Los usos de la madera entre los cazadores-recolectores Selknam de Tierra del Fuego. Treball de recerca-Doctorat d'Arquelogía Prehistòrica, Universitat Autónoma de Barcelona.

Caruso Fermé L (2012) Modalidades de adquisición y uso del material leñoso entre grupos cazadores-recolectores patagónicos (Argentina). Métodos y técnicas de estudios del material leñoso arqueológico. Doctoral Thesis, Universitat Autònoma de Barcelona (July 2012). Available at: https:// www.educacion.es/teseo/mostrarRef.do?ref=986004.

Caruso Fermé L, Mansur E and Piqué R (2008) Voces en el bosque: eluso de recursos vegetales entre cazadores-recolectores de la zona central de tierra del fuego. Darwiniana (Publicación Botánica, Instituto de botánica Darwinion) 46(2): 202-212.

Caruso Fermé L, Théry-Parisot I and Piqué R (2013a) ¿Recolectar o cortar?: modalidades de adquisición del material leñoso en cazadores-recolectores de Patagonia. In: Zangrando F, Barberena R, Gil A et al. (eds) Tendencias teórico-metodológicas y casos de estudio en la arqueología de la Patagonia. Buenos Aires: Museo de Historia Natural de San Rafael, Sociedad Argentina de Antropología e Instituto Nacional de Antropología y Pensamiento Latinoamericano, pp. 281-287.

Caruso Fermé L, Clemente I, Beyries S. (2013b) Wood technology of Patagonian hunter-gatherers A use-wear analysis study from the site of Cerro Casa de Piedra 7 (Patagonia, Argentina). In: International conference on use-wear analysis, Faro, 10-12 October 2012.

Chabal L (1997) Forêts et sociétés en Languedoc (Néolithique final, Antiquité tardive), L'anthracologie, méthode et paléoécologie. Paris: Documents d'Archéologie Française, 188 pp.

Chabal L, Fabre JF and Théry-Parisor I (1999) L'anthracologie. In: La Botanique (Colletion Archéologiques). Paris: Errance, pp. 43-104.

Civalero MT and Aschero CA (2003) Early occupations at Cerro Casa de Piedra 7, Santa Cruz Province, Patagonia Argentina. In: Miotti L, Salemme M and Flegenheimer N (eds) Ancient Evidence for Paleo South Americans. From Where the South Winds Blow. College Station, TX: Center for the Studies of the First American (CSFA), Texas A\&M University Press, pp. 141-147.

Civalero MT and De Nigris ME (2005) Explotación de fauna y tecnología lítica en Cerro Ccasa de Piedra 7, Santa Cruz. Relaciones de la Sociedad Argentina de Antropología XXX: 105-122.

Civalero MT and Franco NV (2003) Early human occupations in western Santa Cruz Province, Southernmost South America. Quaternary International 109-110: 77-86.

Civalero MT, Borrazo K, Bozzuto D et al. (2007) ¿Ultimas? excavaciones en Cerro Casa de Piedra 7, Santa Cruz. Arqueología argentina en los inicios de un nuevo siglo (compilers OlivaFDe GrandisNRodríguezJ) I: 329-335.

Civalero MT, Bozzuto DL, Di Vruno A et al. (2006-2007) Cerro Casa de Piedra, una fecha diferente. Cuadernos del Instituto Nacional de Antropología 21: 259-261.

De Nigris ME (2004) El consumo en grupos cazadores recolectores. Un ejemplo zooarqueológico de Patagonia meridional. Buenos Aires: Relaciones de la Sociedad Argentina de Antropología.

Donoso C and Donoso P (2006) Nothofagus betuloides (Mirb) Oerst. Coigüe de Magallanes, Ouchpaya onas), Guindo (zona 
Austral), Coigüe Colorado (Tierra del Fuego). In: Donoso C (ed.) Las especies arbóreas de los bosques templados de chile y argentina. Autoecología. Santiago: Ediciones Marisa Cúneo, pp. 411-423.

Donoso P, Donoso C, Gallo L et al. (2006) Nothofagus oblicua (Mirb.) Oerst Roble, Pellín Hualle. In: Donoso C (ed.) Las especies arbóreas de los bosques templados de chile y argentina. Autoecología. pp. 471-485.

Dufraisse A (2006) Charcoal anatomy potential, wood diameter and radial growth. In: Dufraisse A (ed.) Charcoal Analysis: New Analytical Tools and Methods for Archaeology. Papers from the 'Table-Ronde', Held in Basel 2004 (BAR International Series 1483). Oxford: Archaeopress, pp. 47-60.

Dufraisse A (2008) Firewood management and woodland exploitation during the late Neolithic at Lac de Chalain (Jura, France). Vegetation History and Archaeobotany 17: 199-210.

González M, Donoso C, Ovalle P et al. (2006) Nothofagus pumilio (Poep.et Endl) Krasser. Lenga, roble blanco, leñar, roble de Tierra del Fuego. In: Zegers CD (ed.) Las species arbóreas de los bisques templados de Chile y Argentina. Autoecología. Valdivia: María Cuneo Ediciones, pp. 486-500.

Guerrido C and Fernandez D (2007) Flora Patagonia. Punta Arenas: Fantastico Sur.

Henry A, Théry-Parisot I and Voronkova E (2009) La gestion du bois de feu en forêt boréale: archéo-anthracologie et ethnographie (région de 1'Amour, Sibérie). In: Théry-Parisot I, Costamagno S and Henry A (eds) Gestion des combustiblesau paléolithique et au mésolithique: Nouveaux outils, nouvelles interprétations (BAR International Series 1914). Oxford: Archaeopress, pp. 17-37.

Heusser C (1995) Three Late Quaternary pollen diagrams from Southern Patagonia and their palaeoecological implications. Palaeogeography, Palaeoclimatology, Palaeoecology 118: $1-24$.

Kofalt R and Mascó M (2000) La distribución de la vegetación en la Pcia de Santa Cruz. In: Godoy C (ed.) El gran libro de la Provincia de Santa Cruz. Patagonia and Buenos Aires: Milenio/Alfa, pp. 191-229.T.1.

Kofalt R and Mascó M (2004) Flora. In: Guía Geográfica Interactiva de Santa Cruz. Buenos Aires: Instituto nacional de Tecnología Agropecuaria (INTA).

León RJC, Bran D, Collantes M et al. (1998) Grandes unidades de vegetación de la Patagonia extra andina. Ecología Austral 8: $125-144$

Mancini MV (1997) Vegetational History During the last 7000 Years in the Steppe-forest ecotone, Santa Cruz, Argentina. In: Volkheinmer W and Smolka PP (eds) Southern Hemisphere Paleo and Neoclimates. Methods and Concepts. Cambridge: Cambridge University Press, pp. 143-150.

Mancini MV (1998) Vegetation changes during the Holocene in the Extra-Andean patagonia, Argentina. Palaeogeography, Palaeoclimatology, Palaeoecology 138: 207-219.

Mancini MV (2002) Vegetation and climate during the Holocene in Southwest Patagonia, Argentina. Review of Palaeobotany and Palynology 122: 101-115.

Mancini MV (2007) Cambios paleoambientales en el ecotono bosque-estepa: análisis polínico del Sitio Casa de Piedra 7. Santa Cruz (Argentina). In: Morello F, Martinic M, Prieto A et al. (eds) Arqueología de Fuego-Patagonia. Punta Arenas: Ediciones CECUA, pp. 89-93.

Mancini MV (2009) Holocene vegetation and climate changes from a peat pollen record of the forest - steppe ecotone, Southwest of Patagonia (Argentina). Quaternary Science Reviews 28: 1490-1497.
Mancini MV, Paez MM and Prieto AR (2002) Cambios paleoambientales durante los últimos $700014 \mathrm{C}$ años en el ecotono bosque-estepa, 47-48 S, Santa Cruz, Argentina. Ameghiniana 39(2): 151-162.

Markgraf V, Romero E and Villagrán C (1996) History and Paleoecology of south American Nothofagus Forest. In: Vebeln TT, Hill RS and Read J (eds) The Ecology and Biogeography of Nothofagus Forest. New Haven, CT and London: Yale University Press, pp. 354-386.

Mermoz M (1998) Mapa preliminar de vegetación parque nacional Perito Moreno. Editorial: Dirección nacional de Conservación de Áreas Protegidas. Buenos Aires: Delegación Regional Patagonia.

Morello J (1984) Perfil ecológico de Sudamérica. Caracteristicas estructurales de Sudamérica y su relación con espacios semejantes del planeta. Barcelona: ICI, Ediciones Cultura Hispánica.

Movia CP, Soriano A and León RJC (1987) La vegetación de la cuenca del Río Santa Cruz. Darwiniana 28: 9-78.

Nelson MC (1991) The study of technological organization. In: Schiffer M (ed.) Archaeological Method and Theory, vol. 13. Tucson, AZ: University of Arizona Press, pp. 57-100.

Páez MM, Villagran C and Carrillo R (1994) Modelo de la dispersión polínica actual en la región templada chileno-argentina de Sudamérica y su relación con el clima y la vegetación. Revista Chilena de Historia Natural 67: 417-433.

Peri P (2004) Bosque Nativo. In: Guía Geográfica Interactiva de Santa Cruz. Instituto nacional de Tecnología Agropecuaria (INTA), pp. 43-47.

Picornell Gelabert L (2009) Antracología y etnoarqueología. Perspectivas para el estudios de las relaciones entre las sociedades humanas y su entorno. Cumplutum 20: 133-151.

Picornell Gelabert L, Asouti E and Allué E (2011) The ethnoarchaeology of forewood management in the Fang villages of Equatorial Guinea, central Africa: Implications for the interpretation of Wood fuel remains from archeological sites. Journal of Anthropological Archaeology 30: 375-384.

Roig FA (1998) La vegetación de la Patagonia. Colección Cinetífica INTA VIII(I): 48-174.

Soriano A(1956) Los distritos norísticos de la provincia patagónica. Revista de Investigaciones Agropecuarias 10: 323-347.

Stine S and Stine M (1990) A record from lake Cardiel of climate change in southern South America. Nature 345(6277): 705-708.

Tabuti J, Dihillon S and Lie K (2003) Firewood use in Bulamogi County, Uganda: Species selection, harvesting and consumption patterns. Biomass and Bioenergy 25: 581-596.

Théry-Parisot I (1998) Économie du Combustible et Paléoécologie en contexte glaciaire et périglaciaire, Paléolithique moyen et supérieur du sud de la France. (Anthracologie, Expérimentation, Taphonomie). Thèse de doctorat, Université de Paris I Panthéon-Sorbonne.

Théry-Parisot I and Henry A (2012) Seasoned or green? Radial cracks analysis as a method for identifying the use of green wood as fuel in archaeological charcoal. Journal of Archaeological Science 39: 381-388.

Zapata L (2007) Cazadores-recolectores y recursos vegetales. In: Cacho C, Maicas R, Martos JA et al. (eds) Acercándonos al pasado. Madrid: Museo Arqueológico Nacional, CSIC, pp. $1-6$.

Zapata Peña L, Peña-Chocarro L, Ibanez Estevez JJ et al. (2003) Ethnoarchaeology in the Moroccan Jebala (Western Rif): Wood, dung and fuel. In: Neumann K, Butler A and Kahlheber S (eds) Food, fuel and fields: Progress in African archaeobotany. Africa Praehist 15: 163-175. 